University of Wyoming College of Law

Law Archive of Wyoming Scholarship

$4-10-2010$

\title{
Canaries in the Coal Mine: The Tactical Use of the National Labor Relations Act to Aid in the Protection of Non-Union Workers Exposed to Pollutants
}

\author{
Michael C. Duff \\ University of Wyoming College of Law, michael.duff@slu.edu
}

Follow this and additional works at: https://scholarship.law.uwyo.edu/faculty_articles

\footnotetext{
Recommended Citation

Duff, Michael C., "Canaries in the Coal Mine: The Tactical Use of the National Labor Relations Act to Aid in the Protection of Non-Union Workers Exposed to Pollutants" (2010). Faculty Articles. 63.

https://scholarship.law.uwyo.edu/faculty_articles/63
}

This Article is brought to you for free and open access by the UW College of Law Faculty Scholarship at Law Archive of Wyoming Scholarship. It has been accepted for inclusion in Faculty Articles by an authorized administrator of Law Archive of Wyoming Scholarship. 


\title{
Canaries in the Coal Mine: The Tactical Use of the National Labor Relations Act to Aid in the Protection of Workers Exposed to Pollutants
}

\author{
Michael C. Duff
}

My mother's father was George Parker, a Harlan County, Kentucky coal miner who died at age 59 from black lung. He was well acquainted with the concept of "canaries in the coal mine." Canaries were used in times past to alert miners to the presence of dangerous gases in a mine. A canary would die, and the miners would thereby become aware of deadly, but sometimes odorless, gasses. Just as canaries have alerted miners to the presence of dangerous gasses in mines, workers exposed to dangerous pollutants and conditions in workplaces may function as societal canaries warning the broader public of environmental dangers; but hopefully without having to die in the process.

As the varied themes at this symposium attest, there are diverse perspectives respecting environmental justice. I want to focus here on environmental justice in its occupational dimensions. And I want to emphasize a specific, but not widely known, legal avenue that workers can utilize in avoiding occupational hazards including pollutants. Occupational health is unavoidably enmeshed with environmental justice. The workplace is often the gateway by which pollutants make their way into the environment of the broader community. And, of course, those same pollutants impact directly the workers in those workplaces. It has been well documented that dangerous workplaces are disproportionately comprised of workers of color and by low-wage

\footnotetext{
** Associate Professor of Law, University of Wyoming College of Law. B.A. 1991, West Chester University of Pennsylvania; J.D. 1995, Harvard Law School. This essay was delivered at the Shepard Symposium on Social Justice, University of Wyoming, April 8, 2010.
} 
workers, so evident justice issues are presented even before consideration of gateway effects. ${ }^{1}$

George Friedman-Jiminez, an occupational medical doctor and long time director of Bellevue Hospital's Occupational and Environmental Health Clinic in New York City, has written extensively about the relationship between environmental justice and occupational health. Dr. Friedman-Jiminez has observed that, "clinical occupational medicine and occupational epidemiology have probably provided the greatest body of evidence of actual human health effects of environmental exposures." ${ }^{2}$ In a very real sense the workplace is a laboratory within which dangerous environmental pollutants are first identified, and the treatments of illnesses deriving from exposure to those pollutants tested.

In addition to the environmental justice dimensions of what happens within a polluting workplace there is, of course, the extended impact of pollutants escaping the workplace into the surrounding environment. While it is true that environmental pollution knows no boundaries, the first exterior ring of that impact sweeps up communities immediately adjacent to polluting facilities. In this regard, there has been incontrovertible evidence for almost two decades that "toxic waste sites are preferentially

\footnotetext{
1 Rafael Moure-Eraso and George Friedman-Jiminez, Occupational Health Among Latino Workers: A Needs Assessment and Recommended Interventions in NEW SOLUTIONS: A JOURNAL OF ENVIRONMENTAL AND OCCUPATIONAL HEALTH POLICY, 319 - 347 Volume 14, Number 4 (2004)
} 
located closer to communities of color and low income communities." ${ }^{13}$ Moreover, "[e]xposures to urban air pollution, lead and other environmental toxins [also] tend to be more common in these communities ..."4 From this it follows that workers' protest of exposure to pollutants can serve dual purposes. The protest can both protect their own health, possibly immediately limiting pollutant dispersal in the community, and, if their protest becomes publicized, inform the community of potential environmental pollution.

While I am primarily thinking of operational dangers, workers may uncover environmental risks even before a polluting facility has been put into operation, thereby providing communities with very early warning of the need for future close monitoring of the facility.

There are some prominent recent examples of the "gateway" idea I have been describing in the abstract. One such example has arisen over a couple of decades in the context of industrial farm animal production (ifap). The Pew Foundation's 2006 study, Putting Meat on the Table, documented the relationship between workers' exposure to animal waste in ifap facilities and subsequent health effects on the surrounding community, which is often rural and poor. The study demonstrated that health risks can extend far from an ifap facility. Groundwater contamination may extend throughout a neighboring aquifer, affecting drinking water supplies far from the source of pollution.

3 Id. at 605, citing UNITED CHURCH OF CHRIST, COMMISSION FOR RACIAL JUSTICE, TOXIC WASTES AND RACE IN THE UNITED STATES (1987)

4 Id., citing Barry L. Johnson et al., Proceedings of the National Minority Health Conference: Focus on Environmental Contamination ix (1992); CONFRONTING ENVIRONMENTAL RACISM: VOICES FROM THE GRASSROOTS (Robert D. Bullard, ed. 1993) 
Infectious agents arising in ifap facilities may be transmissible from person to person in a community setting and well beyond. Significantly, the study showed that "agricultural workers may serve as a bridging population between their communities and animal confinement facilities." Thus, the line between dangerous occupational conditions and broader environmental pollution can be a very thin one.

A second, narrower, instance of the gateway idea was exemplified by an industrial accident occurring in Connecticut this past February. Industrial accidents are admittedly a variation on the pollutant exposure theme, but I think they similarly reflect the close connection between workplace hazards and community safety. The accident in question transpired during the construction of a gas and oil fired power plant to be operated by Kleen Energy Systems in Middletown. The events surrounding the accident underscore an earlier point: a company's handling of risk during the construction of its facility may put a community on notice of the need to closely scrutinize the facility's environmental practices once it becomes operational. The accident itself was an explosion that killed six workers and injured twelve others. The explosion occurred during a planned work activity to clean debris from new natural gas pipes that had been installed in the plant. To remove the debris, workers used natural gas at a high pressure of about 650 pounds per square inch. At pre-determined locations, this gas was vented into the atmosphere through open pipe ends, which were located less than 20 feet from the ground. The vents were next to the main power generation building. This cleaning practice is known within the natural gas power industry as a "gas blow." Industry personnel admitted to Chemical Safety Board investigators that gas blows are a common practice during the commissioning of new or modified gas pipes at oil and gas fired facilities. Records 
confirmed that gas blows had occurred intermittently over the course of the morning of the accident. Potential ignition sources were clearly present inside the power plant building. Initial calculations by CSB investigators revealed that about 400,000 standard cubic feet of gas were released into the facility in the ten minutes leading up to the blast. That is enough gas to fill the entire volume of a pro-basketball arena with an explosive natural gas-air mixture, from the floor to the ceiling.

I will assume that any community would have an interest in preventing both the pollution of its air and water by animal waste and the triggering of nearby explosions. To the extent that workers would be in the immediate path of such hazards their early and vigorous protest of the triggering conditions could both protect themselves and warn the surrounding community of danger. Yet, workers may be unwilling to engage in such a protest out of fear their employers will fire them.

It might be argued that spontaneous worker protests of dangerous conditions are unjustified because they would have or should have handled objections to dangerous work as a matter of contract. After all, the argument might continue, workers are or should be receiving enhanced compensation for risks associated with work hazards. There are at least two problems with this argument. First, workers have to know about hazards in order to negotiate adjusted compensation ex ante. Further, because, as a practical matter, employers have no real legal obligation to disclose job hazards prior to employment, the possibility of negotiation is diminished. Second, the evidence strongly suggests that the more dangerous the job the more likely it is to be filled by workers of color and by low-wage workers. These vulnerable workers are less likely to possess any preexisting hazard information, and it is very unlikely that they would initiate pre- 
employment negotiation. Furthermore, relatively unskilled or geographically isolated workers may have very few job options. Alternatively, workers may have incomplete hazard information, in which case irrational negotiation may occur. To workers from poorer populations $\$ 15$ per hour may seem attractive when compared to the minimum wage, but the wage may take little or no account of the potential for future health problems arising from exposure to hazards. (Ironically, full risk disclosure and fair and complete bargaining might actually represent a loss to the community of the role the worker might have played in disclosing environmental hazards).

But in any event suppose a workplace in which workers are not originally informed of a risk but discover it in the course of employment. If the workers choose to protest exposure to the risk on their own behalf, perhaps derivatively benefitting a nearby community by informing it of hazards, there are various legal avenues that they might pursue to protect their protest. They might report the unsafe condition to the Occupational Safety and Health Administration, OSHA, a federal agency regulating workplace safety under the OSH Act. OSHA has procedures permitting workers to report workplace hazards under the protection of anti-retaliation provisions. Many states have their own mini-OSHA analogues that may have similar anti-retaliation provisions. Workers might also report the hazard to a state workers' compensation system. While workers' compensation statutes are generally meant to compensate workers for injuries sustained in the workplace, some statutes have procedures facilitating employee complaints of unsafe workplace conditions. Some, but not all, workers' compensation systems have statutory or court created anti-retaliation rules protecting workers who file claims or who complain about working conditions. 
In addition to federal and state statutory approaches for protecting worker protest of hazardous working conditions, unionized workers may be covered by collective bargaining agreements containing safety provisions. In these circumstances, workers may file contractual grievances over unsafe workplace conditions that are either resolved voluntarily by the involved union and the employer, or decided by a neutral arbitrator. An employer refusing to arbitrate such a grievance likely violates the National Labor Relations Act (NLRA), and courts frequently compel arbitration in those circumstances. ${ }^{5}$

But aside from OSHA and workers' compensation statutes, what recourse do nonunion workers have? Unknown to many sophisticated observers, and certainly to relatively unsophisticated workers, the NLRA applies not only to unionized workplaces but extends to most non-union workplaces as well. Section 7 of the NLRA confers upon all workers, unionized or not, the right to engage in concerted activities for their mutual aid or protection. This broad protection of workers is not as well known as the narrower right conferred in the same section for workers to select unions for the purpose of engaging in collective bargaining with employers.

How exactly might the NLRA apply to workers protesting hazardous working conditions such as exposure to pollutants? Take the example of the gas venting discussed

\footnotetext{
5 Counterintuitively, unionized workers covered by collective bargaining agreements have less legal latitude in responding to imminent hazards than non-union workers. Because most union contracts have no-strike provisions, workers may find themselves in a complicated situation. Ordinarily, an employer may fire workers striking in breach of a no-strike contractual provision without violating the NLRA. While it is true that Section 502 of the NLRA declares that workers' quitting work because of abnormally hazardous working conditions is not a strike, and would therefore not violate a no-strike provision, the exception has been very narrowly construed by the Supreme Court. Section 502, under the Court's formulation, may only be invoked where workers have must present "ascertainable, objective evidence supporting its conclusion that an abnormally dangerous condition for work exists." Gateway Coal v. United Mineworkers, 414 U.S. 368, 387 (1974). Because workers cannot know at the time of making a decision to flee whether their impression of hazard-often based on a long career of experience-will be in accord with the after-the-fact impression of a distant federal judge, they have a strong, but probably irrational incentive to remain in harm's way.
} 
earlier. If workers had suspected the possibility of an explosion and had simply walked off the job collectively in protest or in self-defense, the action would likely have been protected under the NLRA. In other words, if their employer had fired them for the walkout, the National Labor Relations Board, or NLRB -- the federal agency administering the NLRA -- would probably have ordered them reinstated with backpay. Section 7 claims are of particular importance to workers who engage in spontaneous reaction to imminent hazards. An imminent explosion, for example, -- think of the moments just before the Middletown explosion -- may not leave time for the formal filing of an OSHA complaint or a workers' compensation claim, something that would be needed to trigger OSHA or workers comp anti-retaliatory protections. Section 7, on the other hand, and to a remarkable degree, authorizes workers to act spontaneously to protect themselves.

Before discussing just a few legal cases in which Section 7 has been applied in the specific context of occupational hazards, I would like to make two observations. First, while it is sometimes believed that the NLRA does not apply in so called "right to work" states, this is simply not true. Right to work states have simply opted out of the portion of the NLRA authorizing employers and unions to enter into collective bargaining agreements requiring employees to pay union agency fees. All of the core protections of the NLRA apply with full force in right to work states. Second, the "employment at will" doctrine -- that an employer may fire an employee for a good reason, a bad reason, or no reason at all -- is irrelevant. Employers otherwise under the jurisdiction of federal labor law are never entitled to fire employees in a way that violates that law. Moreover, jurisdiction under the NLRA will be found in connection with all but the smallest 
employers. I was an NLRB prosecutor for almost 10 years and never encountered a case in which the NLRB failed to prevail on jurisdictional grounds in the federal courts. It is a very rare occurrence. ${ }^{6}$

Just a few cases are sufficient to explain how Section 7 has been applied to worker protest of hazards in non-union workplaces. The seminal case is the Supreme Court's 1962 decision in Washington Aluminum. ${ }^{7}$ The facts of the case were straightforward. Seven non-union workers spontaneously walked off the job because it was too cold to work. The employer fired the workers, the NLRB ordered them reinstated, and the case was litigated all the way to the high court, which upheld the NLRB. The Court was unmoved by the employer's argument that the workers had presented no "demand" prior to the walkout and that the case therefore did not involve labor relations or negotiation issues. Nor was the court persuaded by the argument that the workers' actions were unreasonable because on the day of the walkout the employer had been trying to repair the inoperable furnace that was at the core of the dispute. In this regard, the Court stated,

"At the very most, that fact might tend to indicate that the conduct of the men in leaving was unnecessary and unwise, and it has long been settled that the reasonableness of workers' decisions to engage in concerted activity is irrelevant to the determination of whether a labor dispute exists or not."

6 I do not suggest that the NLRB does not have the burden in establishing jurisdiction in the first instance, for it does. My point is simply that it is not difficult for the NLRB to make the required showing. For all practical purposes the matter has been well-settled since the Supreme Court's opinion in Jones and Laughlin Steel, 301 U.S. 1 (1937).

7 N.L.R.B. v. Washington Aluminum Co., 370 U.S. 9 (1962)

8 Id. at 16 
As the Court went on to explain, the broader purpose of the NLRA is to prevent the escalation of labor disputes in order to facilitate "industrial peace."

Washington Aluminum has been further refined in the context of workers' protest of workplace hazards. In a 2002 case, Odyssey Capital Group, ${ }^{9}$ the NLRB found unlawful the firing of three maintenance workers who had refused to enter an apartment because they suspected and feared the presence of unhealthy airborne asbestos. The NLRB ordered the workers reinstated with backpay. Odyssey Capital is important because it forcefully re-emphasized a peripheral point in Washington Aluminum: the reasonableness of workers' concerns about an unhealthy work environment is not scrutinized under present law. Assuming workers honestly believe that an unsafe condition is present, and act together spontaneously in response to the belief, a walkout is protected. This refusal by courts to second-guess workers' responses to perceived dangers is unique and critically important. If workers believe their good faith attempts to collectively protect their safety will be questioned after the fact they are more likely to remain in harm's way.

Returning to a point I have been emphasizing, even though the workers' actions in Odyssey Capital were undertaken for their own protection, the litigation, which was widely reported, brought greater awareness of the asbestos practices in the apartment complex where they worked. Thus, the publicity surrounding the case inured not only to

9337 NLRB 1110 (2002) 
the workers' immediate benefit but also to other tenants in the complex, who were put on notice of possible asbestos hazards.

In a 1996 case, Systems with Reliability, ${ }^{10}$ the NLRB ordered reinstatement of a nonunion worker who had been discharged for threatening to file a complaint with OSHA on behalf of all the workers in the workplace. The worker was one of a group of non-union welders who worked with Methyl Ethyl Ketone (MEK), a degreaser solvent used by the employer -- a broadcast antenna manufacturer -- to clean copper and brass parts. MEK is a hazardous, inflammable material. At trial, the NLRB established that "[o]n several occasions, sparks from welding ignited MEK or rags soaked with MEK, causing fires, and on one occasion, a large fire." The employer admitted that MEK had caused the welders to experience nausea, dizziness, watering of eyes, and skin and throat irritation. After repeated failures by the employer to comply with promises to move the MEK out of the work area, the fired worker threatened to report the situation to OSHA on behalf of all the workers. The employer was located in Ebensburg, Pennsylvania, a small wooded town in western Pennsylvania that had suffered devastating fires in its history. The employer did not appeal the NLRB's reinstatement order, probably because Washington Aluminum had already become well-established precedent.

Organizations dedicated to environmental justice might yield large benefits by disseminating to workers details of the full scope of Section 7's protections. Indeed, new groups like the Blue-Green Alliance, a national organization of labor unions and

10322 NLRB 757 
environmental groups, might be particularly well positioned to undertake such a mission. ${ }^{11}$ Section 7 provides at least some protection to workers who may erroneously assume they are completely without legal recourse when protesting workplace hazards. When these hazards include exposure to pollutants that may subsequently be unleashed on surrounding communities, workers' actions firmly implicate broader notions of environmental justice. Even given the limited NLRA remedies of reinstatement and backpay, Section 7 affords the "canaries in the coal mine" a legal foothold on which they -- and through them affected communities -- can build.

11 This notion seems entirely consistent with Dr. Peter J. Longo's argument, as explicated earlier in this very session, that a ratcheting up of collective power will be necessary to combat environmental racism. Alliances between workers and environmental groups appear to me to be a specific application of that useful, broader conceptualization. See generally Dr. Peter J. Longo, University of Nebraska at Kearney, "Reducing Environmental Racism: Ratcheting Up Group Activity," Shepard Symposium on Social Justice, April 8, 2010. 